\title{
Polar Bear Distribution and Habitat Association Reflect Long-term Changes in Fall Sea Ice Conditions in the Alaskan Beaufort Sea
}

\author{
JEFFREY S. GLEASON ${ }^{1,2}$ and KARYN D. RODE ${ }^{3}$
}

(Received 15 September 2008; accepted in revised form 26 January 2009)

\begin{abstract}
The polar bear (Ursus maritimus) is considered an indicator species of ecosystem health because of its longevity, life-history requirements, reliance on sea ice (i.e., sea ice obligate), and position in the Arctic food web. Polar bear distribution and habitat association should both be reliable signals for environmental perturbation, as the bears respond behaviorally to changes in sea ice extent, the timing and duration of ice formation, and ablation. Polar bears and sea ice conditions were monitored as part of the annual fall bowhead whale (Balaena mysticetus) aerial survey in the Alaskan Beaufort Sea between 1979 and 2005. Habitats associated with polar bear sightings changed during the study, with fewer bears associated with ice (irrespective of ice type and percent) and more bears associated with land and open water. Large-scale differences were documented for both ice type and percent ice cover, particularly in September. In general, the pattern in September (and to a lesser extent in October) included a reduction in old ice and a concomitant increase in open water. In addition, there was an eastward and landward shift in polar bear sightings. From 1979 to 1987, polar bears were observed primarily on ice along the shelf break near Barrow, whereas from 1997 to 2005, polar bears were observed on barrier islands or along the mainland coast near Kaktovik. The changes in polar bear distribution and habitat association appear to reflect a behavioral response by polar bears to changes in ice (type and percent cover) and in the timing of ice formation and ablation.
\end{abstract}

Key words: aerial survey, Alaska, Arctic, climate change, distribution, habitat association, polar bear, sea ice

RÉSUMÉ. L'ours polaire (Ursus maritimus) est considéré comme une espèce indicatrice de la santé de l'écosystème en raison de sa longévité, des besoins de son cycle biologique, de sa dépendance de la glace de mer (c'est-à-dire la glace de mer obligatoire) et de la position qu'il occupe dans le réseau alimentaire de l'Arctique. La répartition de l'ours polaire et son association à un habitat devraient tous deux constituer des signaux fiables en matière de perturbation de l'environnement car le comportement des ours varie en fonction des changements caractérisant l'étendue de glace de mer, la synchronisation et la durée de la formation de la glace, de même que l'ablation. Les ours polaires et les conditions de la glace de mer ont fait l'objet d'une surveillance dans le cadre du levé aérien annuel de la baleine boréale (Balaena mysticetus) effectué à l'automne dans la mer de Beaufort alaskienne entre 1979 et 2005. Au cours de l'étude, les habitats liés aux observations d'ours polaires ont évolué, un moins grand nombre d'ours étant associés à la glace (sans égard au type et au pourcentage de glace) et un plus grand nombre d'ours étant associés à la terre et à l'eau libre. Les différences à grande échelle ont été répertoriées tant pour le type de glace que pour le pourcentage de couche de glace, particulièrement en septembre. En général, la tendance en septembre (et en octobre, dans une moindre mesure) comprenait une réduction de l'ancienne glace de même qu'une augmentation concomitante dans l'eau libre. De plus, on a enregistré un décalage vers l'est et vers l'intérieur des terres en ce qui a trait aux observations d'ours polaires. De 1979 à 1987, les ours polaires ont surtout été observés sur la glace le long du rebord continental près de Barrow, tandis que de 1997 à 2005, les ours polaires ont été observés sur les îles-barrières ou le long de la côte continentale près de Kaktovik. Les changements caractérisant la répartition des ours polaires et l'association à un habitat semblent refléter une réaction comportementale des ours polaires vis-à-vis des changements relatifs à la glace (le type et le pourcentage de la couche) ainsi que de la synchronisation de la formation et de l'ablation de la glace.

Mot clés : levé aérien, Alaska, Arctique, changement climatique, répartition, association à un habitat, ours polaire, glace de mer

Traduit pour la revue Arctic par Nicole Giguère.

\footnotetext{
${ }^{1}$ Corresponding author: Minerals Management Service, Environmental Studies Section, 3801 Centerpoint Drive, Suite 500, Anchorage, Alaska 99503-5823, USA

${ }^{2}$ Current address: U.S. Fish and Wildlife Service, Kulm Wetland Management District, 1 First Street SW, PO Box E, Kulm, North Dakota 58456,USA; jeff_gleason@fws.gov

${ }^{3}$ U.S. Fish and Wildlife Service, Marine Mammals Management, 1011 E Tudor Road, Anchorage, Alaska 99503, USA

(C) The Arctic Institute of North America
} 


\section{INTRODUCTION}

A number of predictions have been advanced regarding potential effects of climate change on Arctic-adapted biota (ACIA, 2004; Derocher et al., 2004; Laidre et al., 2008). The general patterns proposed suggest range contractions for a number of species whose life histories are closely linked with sea ice; at the same time, as sea ice retreats and temperatures increase, range expansions are expected to occur for a number of sub-Arctic species (Tynan and DeMaster, 1997; Simmonds and Isaac, 2007; Laidre et al., 2008; Moore and Huntington, 2008). Changes that affect the base of the Arctic food web, such as variability in the distribution, abundance, and seasonality of under-ice algae, and their resulting bottom-up effects, will be the most dramatic (Hunt et al., 2002; Fraser and Hofmann, 2003; Grebmeier et al., 2006). Using models that linked satellite-derived sea ice data with chlorophyll and a primary productivity algorithm, Arrigo et al. (2008) estimated that primary production in the Arctic increased annually by $27.5 \mathrm{Tg}$ of chlorophyll per year, with $30 \%$ of the increase attributed to decreased minimum summer sea ice extent and 70\% to a longer phytoplankton growing season. Any additional loss of ice during Arctic spring could more than triple the 1998-2002 levels of primary productivity, potentially altering marine ecosystem structure (Arrigo et al., 2008). Ringed seals (Phoca hispida), bearded seals (Erignathus barbatus), and also polar bears (Ursus maritimus) are considered ecosystem sentinels because of their reliance on sea ice and position in the Arctic food web. Polar bears in particular are often cited as the quintessential species for Arctic impacts due to climate change (Norris et al., 2002; Stirling and Derocher, 2007; Moore, 2008; Wiig et al., 2008). In addition to their position in the food web, polar bears are also considered an indicator species in the Arctic because they are sea ice obligates. They are dependent on sea ice as a platform from which to locate and access their primary prey, the ringed seal, and also as a substrate for travelling to find mates and suitable den sites (Ramsay and Stirling, 1988; Garner et al., 1990; Stirling and Derocher, 1993; Stirling, 2002).

Global circulation models (GCM) generally predict earlier onset of melt, delayed onset of freeze-up, and subsequent thinning of Arctic ice cover as consequences of increasing temperatures (Comiso, 2005; Holland et al., 2006; Serreze et al., 2007). Comiso (2002) showed that from 1978 to 2000, the extent of multi-year ice cover (includes open water within perennial ice) declined by $6.5 \%$ per decade, and its area (ice alone) by $8.9 \%$ per decade. In 2007 , perennial ice cover reached the lowest extent recorded during the satellite era, and in 2008 both extent and area measures were among the lowest recorded (Maslanik et al., 2007; Stroeve et al., 2007, 2008). One implication of this retreat in multi-year ice is that the proportion of multi-year ice floes decreases, whereas the proportion of seasonal ice floes increases, with an overall reduction in average thickness and ice cover that makes ice more susceptible to summer melt (Laxon et al., 2003; Comiso, 2005). The most rapid retreat in multi-year ice has occurred in the Beaufort Sea region, where the summer melt period has increased at a rate of 13.1 days per decade (Comiso, 2002, 2003, 2005).

Adverse impacts on polar bears due to advanced break-up of sea ice in the spring or later onset of sea ice in the fall have been documented for several polar bear populations (Obbard et al., 2006; Stirling and Parkinson, 2006; Regehr et al., 2006, 2007a, b; Rode et al., 2007). For example, Stirling et al. (1999) determined that polar bears in western Hudson Bay came ashore earlier and in poorer condition in 1998 than in 1981; they also documented declines in natality during this period. Recent studies of the Southern Beaufort Sea polar bear population have documented similar links between the length of time when ice is present over the continental shelf and bear survival, size, and body condition (Regehr et al., 2007a; Rode et al., 2007). Cherry et al. (2008), comparing blood serum as a physiological biomarker for fasting in polar bears in the eastern Beaufort Sea, documented a dramatic increase in the proportion of fasting bears (from $9.6 \%$ in 1985 and $10.5 \%$ in 1986 to $21.4 \%$ in 2005 and $29.3 \%$ in 2006). The increased number of fasting bears of all age, sex, and reproductive classes corresponded with large-scale changes in Arctic sea ice conditions (Cherry et al., 2008). These studies suggest that a primary mechanism by which sea ice changes affect polar bear populations is via reduced opportunities to forage on preferred prey associated with spatio-temporal reductions in sea ice cover (see also Stirling and Derocher, 1993; Stirling and Øritsland, 1995; Derocher et al., 2004). However, another potentially important effect of reduced sea ice is direct mortality of polar bears associated with long-distance swimming in open water (Monnett and Gleason, 2006).

Identifying the responses of polar bears to changing ice conditions requires long-term data sets, which are rare for the 19 populations. On the basis of more recent reports on sea ice conditions (Durner et al., 2004; Fischbach et al., 2007) and polar bear sightings during surveys in September and October (this study, see also Schliebe et al., 2008), we hypothesized that sea ice conditions have changed, and that polar bear distribution and habitat association should reflect those changes. The present study examined opportunistic polar bear sightings from long-term (1979-2005) fall (Sept-Oct) bowhead whale (Balaena mysticetus) surveys in the Alaskan Beaufort Sea. The objectives were to (1) assess inter- and intra-annual variation in ice types and percent ice cover in the Alaskan Beaufort Sea, (2) describe temporal variation in habitats associated with polar bear sightings, including ice types and percent ice cover, and (3) assess inter- and intra-annual variation in polar bear distribution and relate observed patterns to changes in sea ice conditions.

\section{METHODS}

\section{Study Area and Survey Protocol}

Surveys included a set of randomly chosen transects within established geographic blocks in the Beaufort Sea 


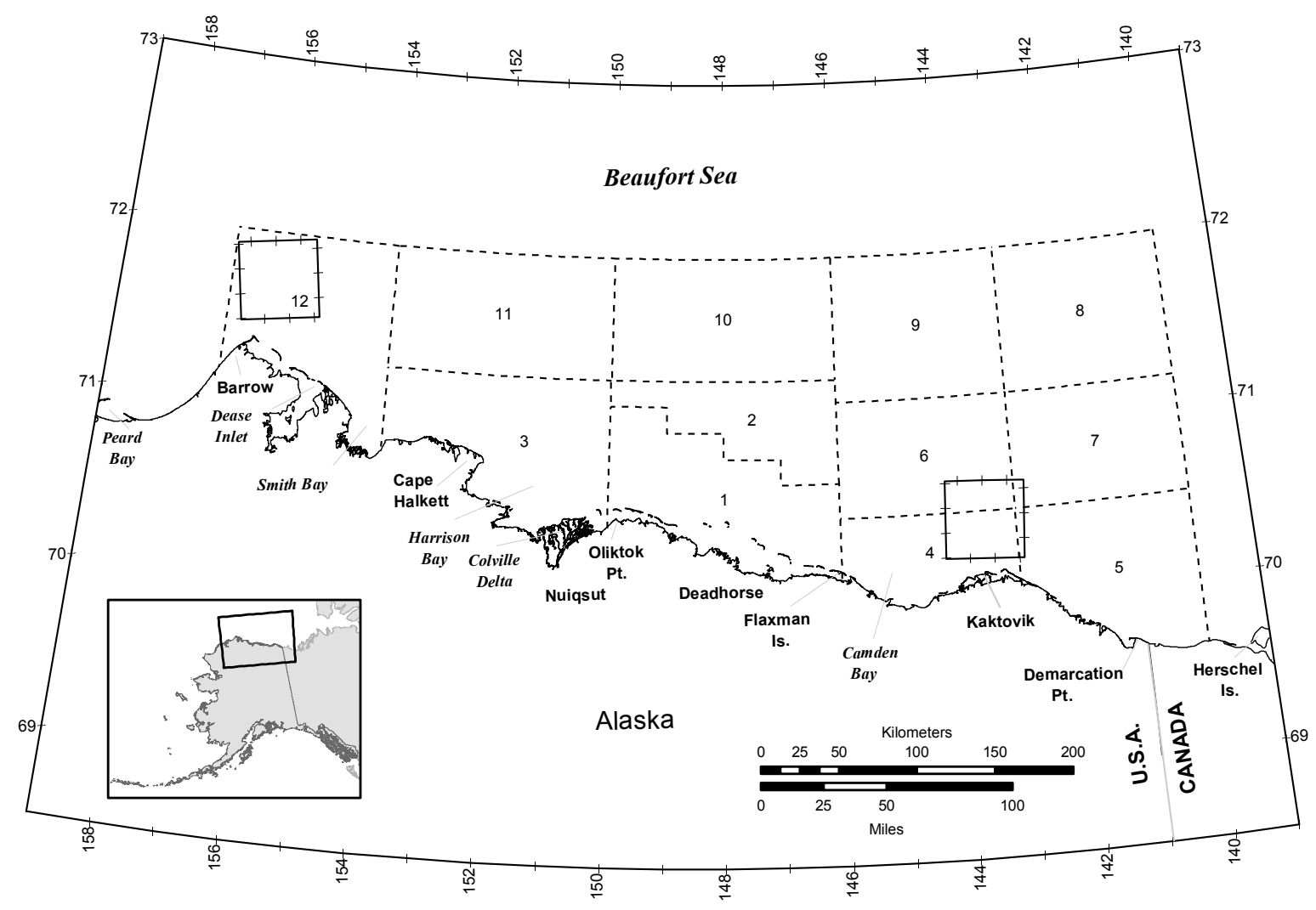

FIG. 1. Study area including aerial survey blocks (dashed lines) and important landmarks along the Alaskan Beaufort Sea coast. The two squares outlined in black represent $50 \times 50 \mathrm{~km}$ ice survey blocks used to determine ice conditions estimated during fall aerial surveys, $1979-2005$.

off the north Alaskan coast (Fig. 1). The eastern boundary of the study area is a line that intersects the coast west of Herschel Island, Yukon, Canada $\left(140^{\circ} \mathrm{W}\right)$ and extends north to roughly $72^{\circ} \mathrm{N}$. The western boundary line intersects the coast just west of Barrow, Alaska $\left(156^{\circ} \mathrm{W}\right)$, also extending north to about $72^{\circ} \mathrm{N}$.

The sea ice environment is a dynamic system composed of a variety of ice types that form masses varying in thickness, composition, and structure. In general, the greatest areal extent of ice in the Beaufort Sea occurs from November through May, and the greatest areal extent of open water and maximum retreat of pack ice occur in August and September (Barnes et al., 1978: Fig 1.1 and Table 1.2). Ice composition, which varies inter- and intra-annually, is strongly influenced by the combined effects of currents, winds, and temperatures, with thickness varying from just a few centimeters for new landfast ice up to several meters or more for older pack ice (Barnes et al., 1978; Reimnitz et al., 1978; Thorndike and Colony, 1982; Norton and Weller, 1984). The general pattern of annual ice drift in the region consists of the Beaufort Gyre, a clockwise or anticyclonic circulation in the Beaufort Sea of the Canadian Basin, with multi-year ice moving away from the Siberian coast and eventually exiting through Fram Strait (Aagaard and Carmack, 1989). Ice ridging within the Alaskan Beaufort Sea appears to vary spatially, with ridging greatest in the eastern portion of our study area near Barter Island (Barnes et al., 1978: Fig. 1.20). Ice dynamics also may affect polar bear distribution and habitat association. During the fall open-water period, for example, rapid deterioration of sea ice often results in a rather abrupt, short-term increase in the number of polar bears onshore along the north coast of Alaska (Durner et al., 2004; Schliebe et al., 2006, 2008).

Annual fall surveys for marine mammals in the Alaskan Beaufort Sea took place from late August to late October, during periods of open water, landfast ice formation, and pack ice encroachment, between 1979 and 2005 (Monnett and Treacy, 2005). While the focus of these surveys was to determine the migration corridor and timing of migration for bowhead whales, sightings of all marine mammals were recorded (Treacy et al., 2006). A sighting represented the location of the aircraft relative to a polar bear at the time the bear was initially spotted and not the actual location of the polar bear. Also, sightings may reflect more than one animal since in some cases several bears were observed at one location. Surveys during 1979-86 were conducted from a Grumman Turbo Goose (Model G21G) equipped with a Global Navigation System 500 (Ljungblad et al., 1986). Since 1987, surveys have been done using a de Havilland Twin Otter Series 300 aircraft equipped with a local Garmin ${ }^{\text {TM }}$ III Global Positioning System (GPS). Surveys were generally flown at a target altitude of $457 \mathrm{~m}$ and a ground speed of approximately $200-250 \mathrm{~km} / \mathrm{h}$. Local weather patterns (wind, precipitation, and fog) affected the timing, frequency, duration, and often effectiveness of all marine mammal surveys. Surveys were aborted when cloud 
ceilings were consistently below $305 \mathrm{~m}$ or when sea state was consistently above Beaufort 4 (Chapman, 1977). In general, from the survey's inception, every effort was made to ensure nearly complete coverage of the entire study area each year (Minerals Management Service, unpubl. data). A more detailed description of survey methodology can be found in Monnett and Treacy (2005).

Three general types of surveys were used: (1) "on transect" surveys of random transects $30 \mathrm{~min}$ of longitude wide and oriented north-south, which varied in length depending on start and end points, (2) "on search" surveys flown to and from transect start and end points that did not follow a predetermined plan, and (3) "on connect" surveys, which linked one transect leg to the next transect leg. Within a given year, decisions related to whether, when, and where to fly were largely driven by local weather patterns, personnel safety concerns, and availability of remaining open water.

Our survey methods may have underrepresented the total number of polar bears present in the survey area as a result of the distance between transects and the altitude of survey flights (457 m) (Manly et al., 1996; McDonald et al., 1999; Evans et al., 2003). Among-observer differences in ability to discriminate polar bears from waves, snow and ice, coupled with inter- and intra-annual variation in survey effort and local weather conditions, also may have influenced the number of polar bear sightings. Furthermore, we had no way to account for variation in search effort or detectability either within a habitat or among habitats "sampled" along random transect lines. The survey targeted open-water habitat, but also included some unknown proportion of all habitats (sea ice, open water, land) available to polar bears. We may have underestimated the number of polar bear sightings associated with sea ice assuming this habitat type was available (Table 1). However, it was never our intent to quantify habitat use per se, or to infer habitat-use decisions, either "preference" or "selection" (Johnson, 1980; Arthur et al., 1996; Thomas and Taylor, 2006). We did not attempt to correct for polar bears potentially missed during surveys; however, the bias thus introduced should be a minor concern, since we were not attempting to derive density or population estimates (see Eberhardt, 1978; Burnham et al., 1980).

\section{Analytical Methods}

Initially, all records of polar bears observed during fall surveys from 1979 to 2005 were selected using an interface between ArcGIS Version 8.3 (ESRI, 1999) and Bowhead Whale Aerial Survey Project (BWASP) software (MicroSoft $^{\text {TM }}$ ACCESS 97). Habitat category was assigned for empty cells within the database (primarily for the period 1979-91) by using ArcGIS to plot individual locations. These "points" included latitude-longitude, date, and a combination of ice type and percent ice cover. Canadian Ice Service (CIS, Environment Canada, Ottawa; cf. Durner et al., 2004) maps generated on or about 15 September of each year allowed a further discrimination of polar bear sightings offshore into either "on ice" or "open water." Habitat was not assigned when additional information contained within the record did not allow interpolation or when point locations, CIS map interpretation, and information contained for a given sighting were incongruent. The "open water" habitat was re-assigned to records only when ice type was recorded as either "no ice" or "grease/new," when ice cover was less than $25 \%$ (most often $0 \%$ ), and when the point location occurred far enough from land to eliminate it as a potential habitat (Monnett and Gleason, 2006).

Fine-scale assessments of ice conditions were done using information assigned for each polar bear sighting, including ice type and percent ice cover. At the time a polar bear was observed, ice type was assessed by the most experienced observer and originally classified into one of the following categories: pack, pack-floe, broken floe, floe, broken-new floe, new-broken floe, grease, frazil, landfast, lead, or no ice. Ice type was reclassified into three broad categories; old ice (pack, pack-floe, broken floe, floe, broken-new floe, new-broken floe, lead), new ice (frazil, grease/new, and landfast), and no ice. Reclassification of ice types generally follows methods described by Durner et al. (2004: Table 1). Also, at the time a polar bear was observed, percent ice cover was estimated by both observers and averaged to the nearest whole percent. The estimate represented a relative assessment of ice cover within viewing distance (inclinometer of $60^{\circ}$ ) from the aircraft. Because percent ice cover estimates resulted in a bimodal distribution (large number of observations at $0 \%$ and above $95 \%$ ) of ice cover observations, three ice cover categories (less than $25 \%, 25-75 \%$, and more than $75 \%$ ) were used.

To assess inter- and intra-annual variation in ice types and percent ice cover in the Alaskan Beaufort Sea, we created two $50 \times 50 \mathrm{~km}$ polygons in ArcGIS (ArcMap; ESRI, 1999), one centered roughly $10 \mathrm{~km}$ north of Barrow and another centered roughly $10 \mathrm{~km}$ north of Kaktovik, using the North American Datum 1983 UTM zone 6N coordinate system. ArcMap was used to query the BWASP database for sea ice cover percents estimated during annual surveys, which were used to generate percentage estimates for both months pooled (Sept and Oct only) within years (1979-87), (1988-96), and (1997-2005) for each of the $50 \times 50 \mathrm{~km}$ blocks (see below).

Contingency analysis (Pearson chi-square; SPSS Inc., 2001) was used to assess large-scale variation in ice type and percent ice cover categories within the $50 \times 50 \mathrm{~km}$ blocks separately for each area (Barrow and Kaktovik), month (September and October), and year range (1979-87, 1988-96, 1997-2005). Contingency analysis was also used to assess temporal variation in frequency of observations relative to ice type, percent ice cover, and habitat categories (ice, land, and water) associated with individual polar bear sightings. Only two categories were considered for percent ice cover classes associated with polar bear sightings-less than $50 \%$ and $50 \%$ or more ice cover $(2 \times 3$ contingency tables) - because $50 \%$ ice cover has previously 
been considered the point at which polar bears abandon ice for land (Stirling et al., 1999), and more than 50\% ice cover is the preferred habitat used by polar bears in the southern Beaufort Sea in the summer and fall (Durner et al., 2004). For all comparisons, observations were assigned to one of three year-groups; early (1979-87), mid (1988-96), and late (1997-2005). An a priori decision was made to partition the dataset into three groups (nine years each) that roughly reflected the stages in changing sea ice conditions during the study, from more heavy ice conditions in 1979-87 to more open-water conditions in 1997-2005 (Treacy et al., 2006).

We used a univariate analysis of covariance (ANCOVA) to test for effects of year (main effect), Julian date (hereafter date; covariate), and their interaction. We tested separately for latitude and longitude as response variables. For this analysis, we considered only those polar bear sightings that occurred on connect and on transect rather than all sightings to reduce potential bias associated with polar bear sightings while on search. Also, to minimize concerns that survey effort might unduly influence results, we assessed potential change in survey effort over time using linear regression for both survey types (on transect and on search). We were able to include data only for surveys flown from 1987 to 2005 because surveys before 1987 included multiple aircraft, searches outside the boundaries defined in this study (Blocks 1-12, see Fig. 1), or surveys in which time (rather than distance) was used as a metric of effort.

Type III sums of squares were used to evaluate significance of effects in polar bear distribution models. A Bonferroni adjustment to account for multiple comparisons was used to define significance level $(p=0.025)$ for ANCOVA models, and similarly, a more conservative alpha level of $p=0.01(p=05 / 3)$ was used for contingency analyses to guard against committing a Type I error (Johnson, 1998). For all contingency analyses, expected values were generated using the equation $C_{\mathrm{e}}=R^{*} C / N$, where $C_{\mathrm{e}}$ represents the expected cell value, $R$ is the expected mean row total associated with that cell, $C$ is the expected mean column total associated with that cell, and $N$ represents the number of comparisons or columns. This approach seemed reasonable given the large differences in observed frequencies (Agresti, 2002). Given the retrospective nature of this observational study, we caution that the findings should not be considered definitive, nor should cause-effect be inferred (Williams et al., 2002). Values reported in figures and tables represent proportions rather than original frequencies used in the contingency analyses.

\section{RESULTS}

\section{Polar Bear Sightings and Survey Effort}

In total, 329 polar bear sightings representing 877 polar bears were made during fall (September-October) surveys in the Alaskan Beaufort Sea from 1979 to 2005 (Fig. 2).
Of these, 66 sightings ( $n=138$ bears) were made during 1979-87, 88 ( $n=271$ bears) during 1988-96, and $175(n=$ 468 bears) in 1997-2005. From 1979 to $1987,48 \%$ of polar bear sightings occurred in September and 52\% in October; from 1988 to 1996, 39\% occurred in September and 61\% in October; and from 1997 to 2005, 73\% occurred in September and $27 \%$ in October. In 2005, there were only 12 polar bear sightings (a total of 18 polar bears), and no sightings occurred on transect.

On average, survey effort can be divided roughly as follows; $48 \%$ on transect, $43 \%$ on search, and $9 \%$ on connect. Survey coverage was limited in most years for the more northerly blocks, in particular blocks 7-10 (Fig. 1). The heavy weighting of the survey effort toward the innermost blocks (1-6 and 12) was due to an emphasis on monitoring fall bowhead whale migration patterns in relation to offshore oil and gas activities. In general, there has been an increase in the proportion of bears sighted on search, but this difference does not appear to be a function of annual variation in effort on search (Monnett and Gleason, 2006: Table 1). There was a slight $(\mathrm{F}=4.25, \mathrm{df}=1,17 ; p=0.05)$ increase in on-transect effort, but on-search effort showed no trend $(\mathrm{F}=0.86, \mathrm{df}=1,17 ; p=0.36)$.

\section{Inter- and Intra-annual Variation in Ice Conditions and Habitats Associated with Polar Bears}

Temporal variation in ice types (old ice, new ice, or no ice) was evident from ice observations within the two 50 $\times 50 \mathrm{~km}$ ice survey blocks located offshore from Barrow and Katovik (Table 1). Ice types differed in the three time periods at both locations. Near Barrow, September had no new ice in any of the time periods, but considerable variation in proportions of old ice and no ice $\left(\chi^{2}=118.27, \mathrm{df}=\right.$ $4, p<0.01)$, while October showed variation in all three ice types $\left(\chi^{2}=48.34\right.$, df $\left.=4, p<0.01\right)$. Near Katovik, differences were also found for both September $\left(\chi^{2}=149.59, \mathrm{df}=\right.$ $4, p<0.01)$ and October $\left(\chi^{2}=55.19, \mathrm{df}=4, p<0.01\right)$. At both locations, open water was encountered more frequently and old ice encountered less frequently during 1997-2005 than during the previous two periods.

Percent ice cover (i.e., $<25 \%, 25-75 \%,>75 \%$ ) differed in September $\left(\chi^{2}=76.97, \mathrm{df}=4, p<0.01\right)$ and October $\left(\chi^{2}=\right.$ 24.44, $\mathrm{df}=4, p<0.01)$ near Barrow. Near Kaktovik, percent ice cover also differed in both September $\left(\chi^{2}=200.20\right.$, $\mathrm{df}=4, p<0.01)$ and October $\left(\chi^{2}=35.38, \mathrm{df}=4, p<0.01\right)$ (Table 1).

Polar bear sightings associated with ice types differed among years in both September $\left(\chi^{2}=130.26, \mathrm{df}=4, p<\right.$ $0.01)$ and October $\left(\chi^{2}=49.04, \mathrm{df}=4, p<0.01\right)$ (Fig. 3a, b). During September, sightings associated with old ice accounted for $88 \%(1979-87), 61 \%(1988-96)$, and $8 \%$ (1997-2005) of all polar bear sightings (Fig. 3a). In $1997-$ $2005,90 \%$ of sightings were associated with no ice, compared to only $12 \%$ of sightings in 1979-87 (Fig. 3). The greater proportion of polar bear sightings associated with ice in October reflects the presence of more ice; however, 
TABLE 1. Variation in ice types and ice cover percentages estimated from fall (September and October) aerial surveys summarized within $50 \times 50 \mathrm{~km}$ blocks overlain in ArcGIS and centered $10 \mathrm{~km}$ offshore from Barrow and Kaktovik, Alaska, 1979-2005 in the southern Beaufort Sea.

\begin{tabular}{|c|c|c|c|c|c|c|c|c|c|c|c|c|c|}
\hline \multirow[b]{3}{*}{ Years } & \multicolumn{6}{|c|}{ Ice Type (\%) } & & \multicolumn{6}{|c|}{ Ice Cover $(\%)$} \\
\hline & \multicolumn{3}{|c|}{ September } & \multicolumn{3}{|c|}{ October } & & \multicolumn{3}{|c|}{ September } & \multicolumn{3}{|c|}{ October } \\
\hline & Old ice & New ice & No ice & Old ice & New ice & No ice & & $<25$ & $25-75$ & $>75$ & $<25$ & $25-75$ & $>75$ \\
\hline & & & & & & & Barrow & & & & & & \\
\hline $1979-87$ & 50 & 0 & 50 & 37 & 20 & 43 & & 72 & 2 & 26 & 51 & 14 & 35 \\
\hline $1988-96$ & 48 & 0 & 52 & 30 & 33 & 37 & & 81 & 10 & 9 & 41 & 18 & 41 \\
\hline \multirow[t]{2}{*}{$1997-2005$} & 3 & 0 & 97 & 34 & 8 & 58 & & 99 & 1 & 0 & 64 & 13 & 23 \\
\hline & & & & & & & Kaktovik & & & & & & \\
\hline $1979-87$ & 45 & 4 & 51 & 24 & 34 & 42 & & 74 & 16 & 10 & 52 & 13 & 35 \\
\hline $1988-96$ & 43 & 3 & 54 & 40 & 9 & 51 & & 72 & 12 & 16 & 54 & 8 & 38 \\
\hline $1997-2005$ & 17 & 0 & 83 & 17 & 14 & 69 & & 100 & 0 & 0 & 78 & 9 & 13 \\
\hline
\end{tabular}

despite the increased availability of ice in October, $31 \%$ of sightings occurred in ice-free conditions during 1997-2005 (Fig. 3b). For both September $\left(\chi^{2}=81.06, \mathrm{df}=2, p<0.01\right)$ and October $\left(\chi^{2}=22.12, \mathrm{df}=2, p<0.01\right)$, there were differences in polar bear sightings over time related to percent ice cover $(<50 \%$ vs. $\geq 50 \%$ ) (Fig. 3c, d). For September, sightings associated with less than $50 \%$ ice cover in $1997-$ 2005 numbered ten times those observed in September 1979-87 and nine times those in September 1988-96 (Fig. 3c). For October, sightings associated with less than $50 \%$ ice cover were $38 \%$ for $1997-2005$ compared to only $22 \%$ for $1979-87$ and $2 \%$ for $1988-96$ (Fig. 3d).

The habitats associated with polar bear sightings (ice, land, or open water; Fig. 3e, f) also differed over time for both September $\left(\chi^{2}=124.28, \mathrm{df}=4, p<0.01\right)$ and October $\left(\chi^{2}=53.32, \mathrm{df}=4, p<0.01\right)$. For the first two time periods (1979-87 and 1988-96), the proportions of habitats associated with sightings were similar for both September and October. However, a major shift to land-based polar bears occurred in the final period, 1997-2005 (Fig. 3e, f).

\section{Inter-and Intra-annual Variation in the Distribution of Polar Bear Sightings}

Included in this analysis were 135 sightings of 246 polar bears on transect and on connect. Latitude (adjusted model $R^{2}=0.648$ ) of polar bear sightings varied as a function of year $(\mathrm{F}=3.93, \mathrm{df}=16,39 ; p<0.01)$ and the yeardate interaction $(\mathrm{F}=3.90, \mathrm{df}=16,39 ; p<0.01)$, but date was not important $(\mathrm{F}=0.63$, $\mathrm{df}=1,39 ; p=0.43)$ (Fig. 2). Parameter estimates $( \pm \mathrm{SE})$ for year $(\beta=-3.23 \pm 0.62)$ and date $(\beta=+0.93 \pm 0.32)$ indicate that the latitude of sightings declined (shifted toward the south) relative to year, but increased (shifted toward the north) as a function of date within year. Longitude (adjusted model $R^{2}=0.579$ ) of polar bear sightings also varied as a function of year $(\mathrm{F}=4.43 \mathrm{df}$ $=16,39 ; p=0.01)$ and the year-date interaction $(\mathrm{F}=4.49$, $\mathrm{df}=16,39 ; p=0.01)$, but date was not important $(\mathrm{F}=2.78$, $\mathrm{df}=1,39 ; \quad p=0.09$ ) (Fig. 2). Parameter estimates for year $(\beta=-14.67 \pm 5.18)$ and date $(\beta=+10.64 \pm 2.70)$ indicate that longitude of sightings declined (shifted toward east) relative to year, but increased (shifted toward west) as a function of date within year.

\section{DISCUSSION}

We documented a change in habitat associated with polar bear observations (Fig. 3) from bears associated with ice to bears found almost exclusively on the barrier islands, on the mainland coast, or in the water (this study; see also Monnett and Gleason, 2006). During the same period, we documented significant changes in both ice type and percent ice cover available to polar bears within the study area (Table 1). In general, there has been a decrease in old ice and a concomitant increase in open water. Similarly, there has been a decrease in "heavy" ice conditions (> 75\% ice) and a subsequent increase in "light" ice conditions $(<25 \%$; primarily $0 \%$ ice) associated with polar bear sightings over the same interval. Results from the sea ice analysis presented in this paper are supported by recent empirical research using satellite ice imagery (Maslanik et al., 1999; Comiso, 2002; Rigor and Wallace, 2004; Overpeck et al., 2005; Lindsay and Zhang, 2005).

The minimum areal extent of sea ice has been documented since 1998, and new record lows were reached in every year from 2002 to 2005 (Maslanik et al., 1999; Stroeve et al., 2005), and again in 2007 and 2008 (NSIDC, 2008). Rode et al. (2007) documented declines in bear size, body mass, and cub survival and determined that at least some of those changes were associated with the increase in duration of the open-water season. Regehr et al. (2007a) documented declines in survival of adult females and cubsof-the-year during recent years with longer ice-free periods (2000-05). Further, Regehr et al. (2007b) documented an increase in the number of days within a year that are considered "ice-free" (defined as $<50 \%$ ice cover); the overall annual mean number of ice-free days increased by 16.7 days from 1979 to 2006.

A within-season south-to-north shift in polar bear distribution was also documented during our study. Sightings in September tended to be concentrated in the nearshore 

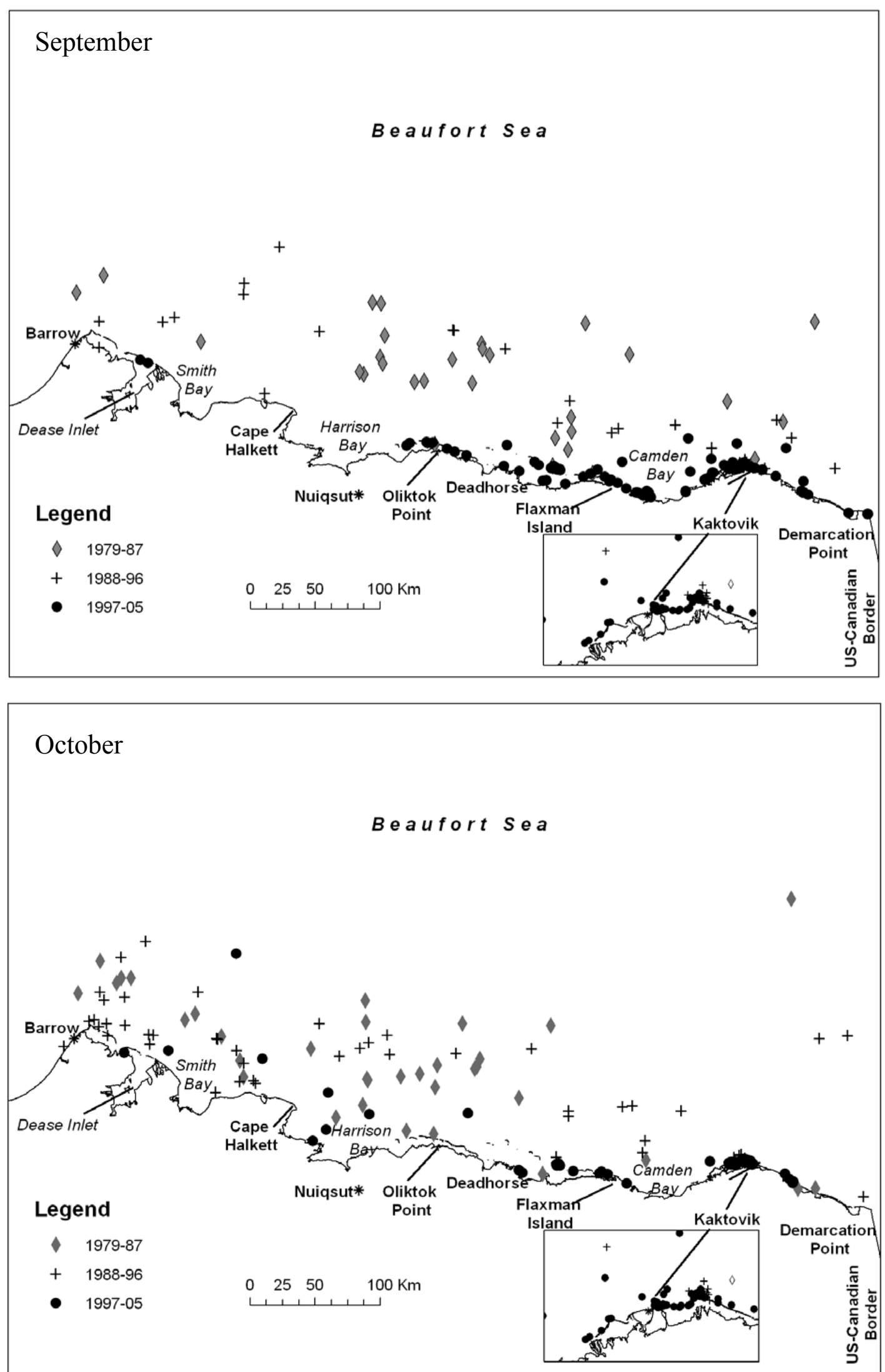



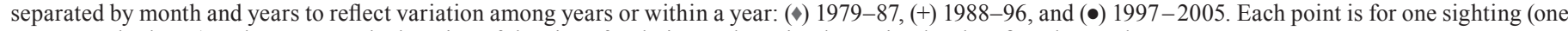
or more polar bears) and represents the location of the aircraft relative to the animal or animals when first detected. 


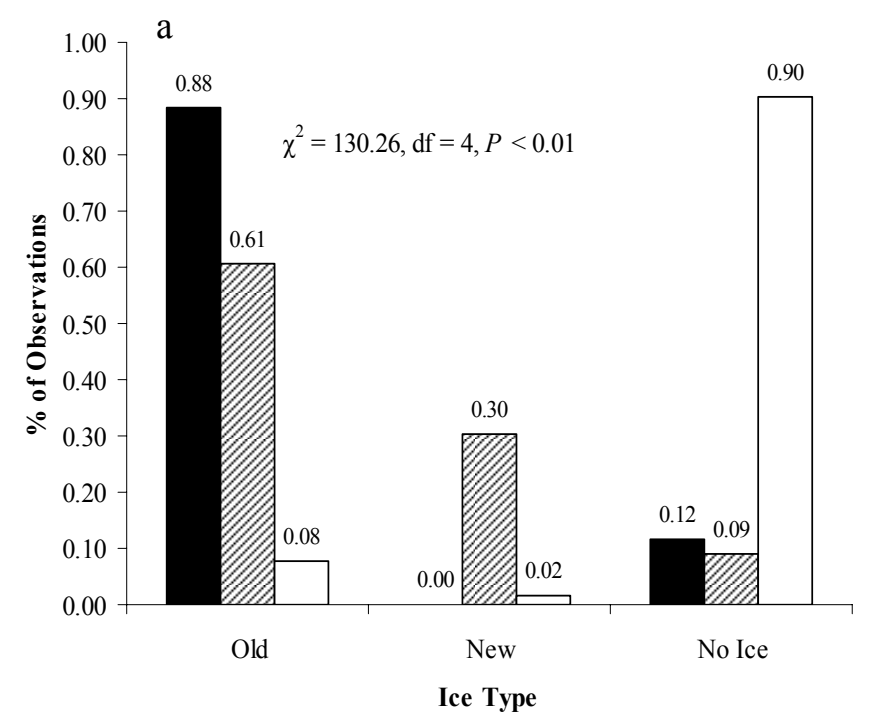

b
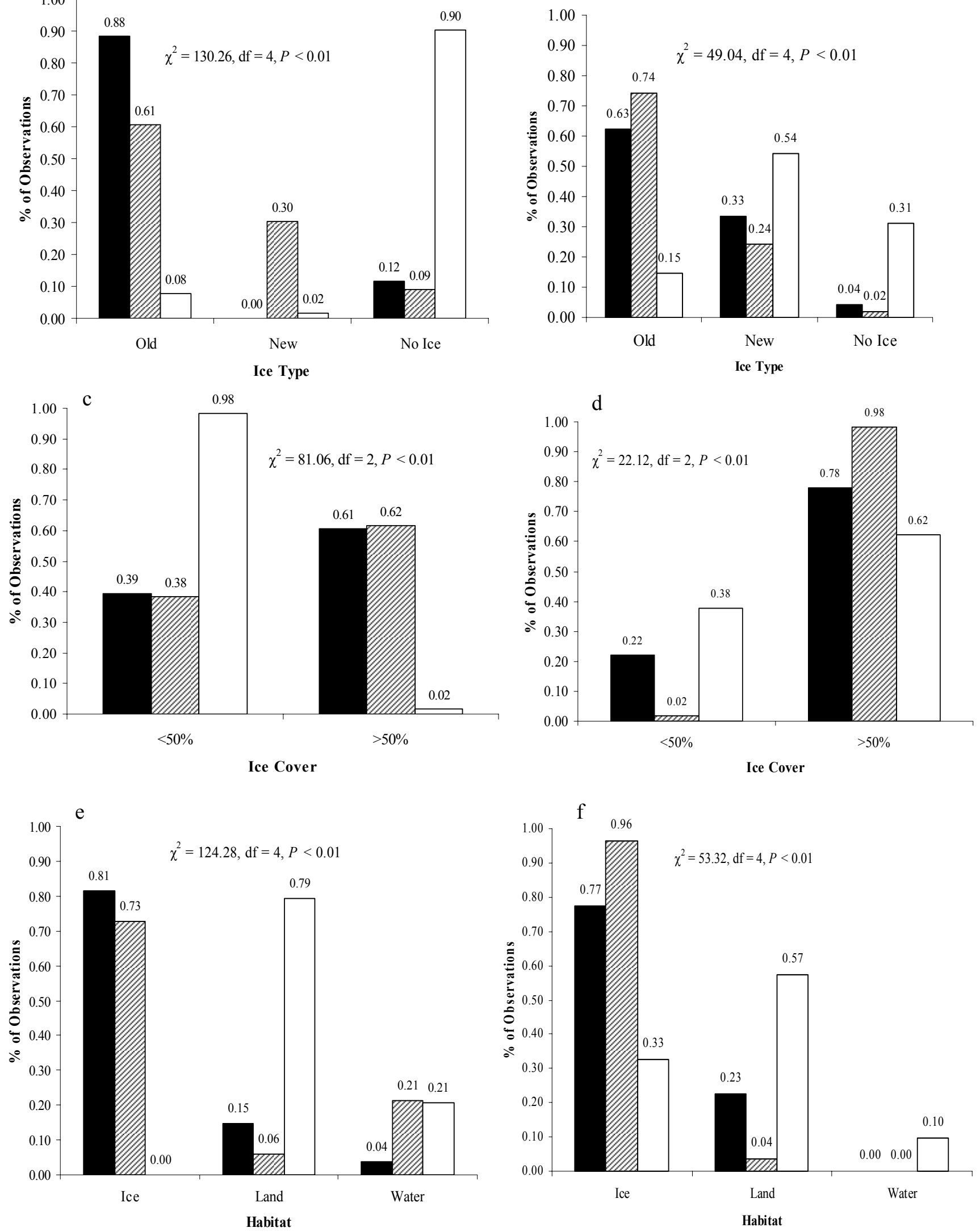

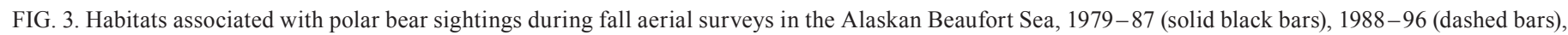

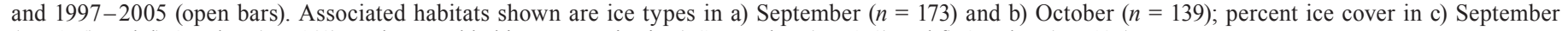
$(n=176)$ and d) October $(n=142)$; and general habitat categories in e) September $(n=172)$ and f) October $(n=137)$. 
environment, particularly in recent years, whereas sightings in October generally occurred farther offshore. It is likely that polar bears on land in September moved onto the ice as soon as it became available as a suitable substrate from which to access ringed seals (Amstrup, 2000; Amstrup et al., 2000; Durner et al., 2004). North-south and south-north seasonal movements were demonstrated by Amstrup et al. (2000) for radio-collared female polar bears in the Beaufort Sea, and the bears' movements were correlated to patterns of ice formation and disintegration (Amstrup et al., 2000; see also Gloersen et al., 1992: Fig. 3.1).

An interannual shift in the distribution of polar bear sightings in the Alaskan Beaufort Sea was also documented (Fig. 2). From 1979-87 to 1997-2005, sightings in the west declined and sightings in the east increased. The largest aggregations ( $>20$ animals) of polar bears documented were observed in the eastern portion of the study area, and only one of those sightings occurred during 1979-87 (9 October 1981). Nearly all sightings of large aggregations were directly associated with the presence of bowhead whale carcasses. Other aggregations of 10 or more animals also occurred more frequently in the east during 1997-2005, with single sightings of more than 10 animals near Deadhorse (Cross Island) and Barrow (Barrow Spit). In addition, survey data suggest that bowhead whale carcasses are concentrating large numbers of polar bears during the fall near the native community of Kaktovik (Brower et al., 2002; Miller et al., 2006; Schliebe et al., 2008). To our knowledge, no data exist indicating that the number of bowhead whale carcasses available to polar bears has increased over time or changed spatially from west to east on land (i.e., since the 1970s; see Koski et al., 2005). The increasing number of bears sighted during our study is supported by both anecdotal reports of increased bear visits in the vicinity of oilfields (Amstrup, 2000; Perham, 2005) and results of recent nearshore polar bear surveys conducted from the Canadian border to Barrow (Schliebe et al., 2008). The large number of sightings along the mainland coast and on barrier islands, and particularly of swimming bears near Kaktovik (and to a lesser extent near Deadhorse), appears to be a recent phenomenon (Miller et al., 2006). There appears to be an increase in the number of land-denning polar bears in the Beaufort Sea with ca. $80 \%$ of the dens located in just $23 \%$ of the available habitat, primarily in the northeast corner of Alaska (Amstrup and Gardner, 1994; Amstrup, 2000; Fischbach et al., 2007). This shift in distribution and habitat use by denning female polar bears (from dens located primarily on sea ice to dens located primarily on land) may at least partially account for the west-to-east shift observed in our study. In addition to the presence of bowhead whale carcasses, high densities of ringed seals may also contribute to the west-to-east shift in polar bear distribution (Schliebe et al., 2008). Frost et al. (2004) documented the highest density of ringed seals from spring aerial surveys at ca. $144^{\circ} \mathrm{W}$, roughly from Kaktovik to Flaxman Island (Fig. 1). Though the evidence is somewhat equivocal, ringed seal sighting data from fall aerial surveys suggest a higher frequency of sightings and larger groups of ringed seals in the eastern portion of the study area, particularly in September, during more recent years (2000-05) (Minerals Management Service, unpubl. data). Schliebe et al. (2008) documented that southern Beaufort Sea polar bear distribution on land was correlated with distribution of bowhead whale carcasses and ringed seal density offshore.

Polar bear sightings increased during this study, which may represent an increasing reliance on barrier islands and the Alaskan north coast as habitat due to recent changes in sea ice conditions. In the Canadian Arctic, Stirling and Parkinson (2006) noted an increase in the number of polar bears reported on land by residents of coastal communities; however, they warned against interpreting this increase in reports as evidence for actual population increases. Rather, they suggested an interpretation similar to ours: that the apparent increase was most likely a result of changing distribution associated with sea ice conditions (see also Schliebe et al., 2008).

Because of its longevity and timing, this study provided a unique framework for assessing potential change in sea ice conditions and describing distribution and habitat association of polar bears in the Alaskan Beaufort Sea during the fall. We understand that the statistical methods used are not the most robust for modeling a suite of complex factors (main effects, covariates, and interactions) that act simultaneously or interact to explain polar bear habitat use, habitat selection, or habitat preference, but that was not our intent. Rather we employed a straightforward approach to describe variability in sea ice and concomitant changes in polar bear distribution and their associated habitats at a relatively large spatiotemporal scale. We have no way to account for detectability issues that may have varied among years, among observers, or among habitats. We further recognize that detection probability is almost certainly higher on land and in open water than on sea ice, and that large groups of bears are easier to detect than individuals. We attempted to "control" for these differences in our analysis, but we recommend that our habitat association results be interpreted with caution.

Observations from our study confirm reductions in ice availability reported from studies using remotely collected ice imagery data. Our results suggest that polar bear habitat associations have changed as a result of reductions in ice availability and that, in particular, more bears are occurring on land and in open water during the fall (SeptemberOctober). Our results and more recent research on polar bears in the Alaskan Beaufort Sea (Amstrup et al., 2006; Monnett and Gleason, 2006; Regehr et al., 2006, 2007b; Fischbach et al., 2007; Hunter et al., 2007; Rode et al., 2007; Schliebe et al., 2008) suggest changes in polar bear distribution, habitat use, and behavior associated with large-scale habitat changes (i.e., loss and fragmentation of sea ice). The eastern Alaskan Beaufort Sea, including the nearshore (barrier islands) and onshore environment, seems to be attracting larger numbers of polar bears than it did historically (Amstrup, 2000; this study). These habitat changes have occurred over a short time frame (ca. 30-40 yrs). 
The increased proportion of polar bear sightings associated with land and open water in our study has implications for management agencies that deal with polar bear-human interactions. Increased use of land by bears is likely to result in increased interactions between polar bears, industry, and Native communities along the Alaskan Beaufort Sea coast. It may be that polar bears, predominantly females with dependent offspring (Miller et al., 2006; Schliebe et al., 2008; this study), use a readily available and relatively constant (in time and space) food source such as bowhead whale carcasses in September and October to supplement their diets because of their high energetic demands prior to moving onto the sea ice in late fall (Bentzen et al., 2007). Such a predictable and readily available high-fat food source presumably has positive long-term reproductive or survival consequences; however, it may negatively affect survival of females and their dependent offspring in the short term if the presence of whale carcasses increases the potential for intra- and inter-specific aggressive encounters or bearhuman interactions that ultimately result in the "take" of problem bears (Amstrup, 2000; Brower et al., 2002; Miller et al., 2006). Concentrations of polar bears attracted to bowhead whale carcasses were identified as a major management concern for the Southern Beaufort Sea polar bear population (Perham, 2005).

The extent of oil and gas activities and development on the southern Beaufort Sea coast continues to increase, and the timing of much activity overlaps with the fall openwater period when bears come to land or are increasingly found in open water. While mitigation measures in place have attempted to minimize impacts to polar bears from industry activities (vessel traffic, seismic operations, and other development-related interactions) in open water, until now it has been mostly assumed that potential impacts of industry on polar bears in open water would be negligible. Results from this study suggest that the frequency of interactions between industry and polar bears during the fall may increase in the future, and that future environmental impact statements, environmental assessments, and Section 7 consultations related to offshore oil and gas activities (e.g., consultations between the U.S. Minerals Management Service and the U.S. Fish and Wildlife Service on oil and gas activities in federal waters relative to polar bears) need to take into account the increasing numbers of polar bears on barrier islands, along the mainland coast, and in open water (Stirling, 1988, 1990; Durner et al., 2000; this study). We believe it is imperative that decision-makers recognize the importance of this new information in light of a changing Arctic sea ice environment.

\section{ACKNOWLEDGEMENTS}

We wish to recognize Steve Treacy's efforts as BWASP research manager for a significant portion of the project's duration (1987-2003). We acknowledge the efforts of numerous personnel from the Minerals Management Service and other agencies who participated in BWASP in various capacities during the project. The services, knowledge, and skills provided by staff and pilots of ERA, Inc. who participated in the surveys, as well as support from the Department of Interior, Office of Aircraft Services, Anchorage, Alaska, are greatly appreciated. Project data collection and field analysis programs used throughout were designed by John Bennett, John Dunlap, and Tom Murrell. Matt Heller and Michael Hay, GIS analysts with Resource Data, Inc., in Anchorage, Alaska, assisted with data management and retrieval, as well as figure preparation. Earlier versions of this manuscript benefited greatly from reviews by or discussions with Lisa Rotterman, Jim Wilder, Scott Schliebe, Tom Evans, Susan Miller, Craig Perham, and Rosa Meehan. This manuscript came to fruition through insightful discussions with and support from Chuck Monnett, BWASP manager from the Alaska Region Minerals Management Service. This paper benefited greatly from comments provided by Andrew Derocher, Karen McCullough, and two anonymous reviewers. Funding for BWASP surveys was provided by the U.S. Minerals Management Service, Alaska Outer Continental Shelf Region. The findings and conclusions in this paper are solely those of the authors and do not necessarily represent the views of the funding agency. Any mention of trade names is purely coincidental and does not represent endorsement by the funding agency or the government.

\section{REFERENCES}

Aagaard, K., and Carmack, E.C. 1989. The role of sea ice and other fresh water in the Arctic circulation. Journal of Geophysical Research 94:14485-14498.

ACIA (Arctic Climate Impact Assessment). 2004. Impacts of a warming climate: Arctic Climate Impact Assessment. Cambridge: Cambridge University Press. 140 p.

Agresti, A. 2002. Categorical data analysis, 2nd ed. Hoboken, New Jersey: John Wiley and Sons, Inc.

Amstrup, S.C. 2000. Polar bear. In: Truett, J.C., and Johnson, S.R., eds. The natural history of an Arctic oil field: Development and biota. San Diego, California: Academic Press. 133-157.

Amstrup, S.C., and Gardner, C. 1994. Polar bear maternity denning in the Beaufort Sea. Journal of Wildlife Management $58: 1-10$.

Amstrup, S.C., Durner, G.M., Stirling, I., Lunn, N.J., and Messier, F. 2000. Movements and distribution of polar bears in the Beaufort Sea. Canadian Journal of Zoology 78:948-966.

Amstrup, S.C., Stirling, I., Smith, T.S., Perham, C., and Thiemann, G.W. 2006. Recent observations of intraspecific predation and cannibalism among polar bears in the southern Beaufort Sea. Polar Biology 29:997-1002.

Arrigo, K.R., VanDijken, G., and Pabi, S. 2008. Impact of ashrinking Arctic ice cover on marine primary production. Geophysical Research Letters 35:L19603, doi:10.1029/2008GL035028.

Arthur, S.M., Manly, B.F.J., McDonald, L.L., and Garner, G.W. 1996. Assessing habitat selection when availability changes. Ecology 77:215-227.

Barnes, P., Belon, C., Coon, M., Hanson, A., Harrison, W., Hoskins, E., Hunt, W., et al. 1978. The sea ice environment. In: 
Shapiro, L., and Barry, R.G., eds. Environmental assessment of the Alaskan Continental Shelf, Interim synthesis: Beaufort/Chukchi. Boulder, Colorado: National Oceanic and Atmospheric Environmental Research Laboratories. 3-55.

Bentzen, T.W., Follmann, E.H., Amstrup, S.C., York, G.S., Wooler, M.J., and O'Hara, T.M. 2007. Variation in winter diet of southern Beaufort Sea polar bears inferred from stable isotope analysis. Canadian Journal of Zoology 85:596-608.

Brower, C.D., Carpenter, A., Branigan, M.L., Calvert, W., Evans, T., Fischbach, A.S., Nagy, J.A., Schliebe, S., and Stirling, I. 2002. The Polar Bear Management Agreement for the southern Beaufort Sea: An evaluation of the first ten years of a unique conservation agreement. Arctic 55:362-372.

Burnham, K.P., Anderson, D.R., and Laake, J.L. 1980. Estimation of density from line transect sampling of biological populations. Wildlife Monographs 72. 202 p.

Chapman, C.F. 1977. Piloting, seamanship and small boat handling. New York: Hearst Books.

Cherry, S.G., Derocher, A.E., Stirling, I., and Richardson, E.S. 2008. Fasting physiology of polar bears in relation to environmental change and breeding behavior in the Beaufort Sea. Polar Biology 32:383-391, doi:10.1007/s00300-0080530-0

Comiso, J.C. 2002. A rapidly declining perennial sea ice cover in the Arctic. Geophysical Research Letters 29(20), 1956, doi:10.1029/2002GL015650.

- 2003. Warming trends in the Arctic from clear sky satellite observations. Journal of Climate 16:3498-3510.

2005. Impact studies of a $2^{\circ} \mathrm{C}$ global warming on the Arctic sea ice cover. In: Rosentrater, L., ed. Evidence and implications of dangerous climate change in the Arctic. Oslo, Norway: WWF International Arctic Programme. 74 p.

Derocher, A.E., Lunn, N.J., and Stirling, I. 2004. Polar bears in a warming climate. Integrated and Comparative Biology 44:163-176.

Durner, G.M., Amstrup, S.C., and McDonald, T.L. 2000. Estimating the impacts of oil spills on polar bears. Arctic Research 14:33-37.

Durner, G.M., Amstrup, S.C., Neilson, R., and McDonald, T.L. 2004. The use of sea ice habitat by female polar bears in the Beaufort Sea. Outer Continental Shelf (OCS) Study, MMS 2004-014. Anchorage: U.S. Geological Survey, Alaska Science Center. 41 p. http://www.mms.gov/alaska/ reports/2004Reports/2004-014.pdf.

Eberhardt, L.L. 1978. Transect methods for population studies. Journal of Wildlife Management 42:1-31.

ESRI (Environmental Systems Research Institute). 1999. ArcView GIS v. 3.2. Redlands, California: ESRI.

Evans, T.J., Fischbach, A., Schliebe, S., Manly, B., Kalxdorff, S., and York, G. 2003. Polar bear aerial survey in the eastern Chukchi Sea: A pilot study. Arctic 56:359-366.

Fischbach, A.S., Amstrup, S.C., and Douglas, D.C. 2007. Landward and eastward shift of Alaskan polar bear denning associated with recent sea ice changes. Polar Biology 30:1395-1405.

Fraser, W.R., and Hofmann, E.E. 2003. A predator's perspective on causal links between climate change, physical forcing and ecosystem response. Marine Ecology Progress Series 265: $1-15$.
Frost, K.J., Lowry, L.F., Pendleton, G., and Nute, H.R. 2004. Factors affecting the observed densities of ringed seals, Phoca hispida, in the Alaskan Beaufort Sea, 1996-99. Arctic 57: $115-128$.

Garner, G.W., Knick, S.T., and Douglas, D.C. 1990. Seasonal movements of adult female polar bears in the Bering and Chukchi seas. International Conference on Bear Research and Management 8:219-226.

Gloersen, P., Campbell, W.J., Cavalieri, D.J., Comiso, J.C., Parkinson, C.L., and Zwally, H.J. 1992. Arctic and Antarctic sea ice, 1978-1987: Satellite passive microwave observations and analysis. NASA Special Publication 511. 290 p.

Grebmeier, J.M., Overland, J.E., Moore, S.E., Farley, E.V., Carmack, E.C., Cooper, L.W., Frey, K.E., Helle, J.H., McLaughlin, F.A., and McNutt, S.L. 2006. A major ecosystem shift in the northern Bering Sea. Science 311:1461 - 1464.

Holland, M.M., Bitz, C.M., and Tremblay, B. 2006. Future abrupt reductions in the summer Arctic sea ice. Geophysical Research Letters 33:L23503, doi:10.1029/2006GL028024.

Hunt, G.L., Jr., Stabeno, P., Walters, G., Sinclair, E., Brodeur, R.D., Napp, J.M., and Bond, N.A. 2002. Climate change and control of the southeastern Bering Sea pelagic ecosystem. Deep Sea Research II 49:5821 - 5853.

Hunter, C.M., Caswell, H., Runge, M.C., Regehr, E.V., Amstrup, S.C., and Stirling, I. 2007. Polar bears in the southern Beaufort Sea II: Demography and population growth in relation to sea ice conditions. Administrative Report. Reston, Virginia: U.S. Geological Survey, U.S. Department of the Interior. http://www.usgs.gov/newsroom/special/polar_bears/docs/ USGS_PolarBear_Hunter_SB-I_Demography.pdf. 46 p.

Johnson, D.E. 1998. Applied multivariate methods for data analysts. Pacific Grove, California: Brooks/Cole Publishing Co.

Johnson, D.H. 1980. The comparison of usage and availability measurements for evaluating resource preference. Ecology 61:65-71.

Koski, W.R., George, J.C., Sheffield, G., and Galginaitis, M.S. 2005. Subsistence harvests of bowhead whales (Balaena mysticetus) at Kaktovik, Alaska (1973-2000). Journal of Cetacean Research and Management 7:33-37.

Laidre, K.L., Stirling, I., Lowry, L.F., Wiig, Ø., Heide-Jørgensen, M.P., and Ferguson, S.H. 2008. Quantifying the sensitivity of Arctic marine mammals to climate-induced habitat change. Ecological Applications 18(Supplement):S97-S125.

Laxon, S., Peacock, N., and Smith, D. 2003. High interannual variability of sea ice thickness in the Arctic region. Nature 425:947-950.

Lindsay, R.W., and Zhang, J. 2005. The thinning of Arctic sea ice, 1988-2003: Have we passed a tipping point? Journal of Climate 18:4879-4894.

Ljungblad, D.K., Moore, S.E., and Van Schoik, D.R. 1986. Seasonal patterns of distribution, abundance, migration and behavior of the Western Arctic stock of bowhead whales, Balaena mysticetus, in Alaskan seas. Report of the International Whaling Commission (Special Issue 8):177-205.

Manly, B.F.J., McDonald, L.L., and Garner, G.W. 1996. Maximum likelihood estimation for the double-count method with 
independent observers. Journal of Agricultural, Biological, and Environmental Statistics 1:170-189.

Maslanik, J.A., Serreze, M.C., and Agnew, T. 1999. On the record reduction in 1998 Western Arctic sea-ice cover. Geophysical Research Letters 26:1905-1908.

Maslanik, J.A., Fowler, C., Stroeve, J., Drobot, S., Zwally, J., Yi, D., and Emery, W. 2007. A younger, thinner Arctic ice cover: increased potential for rapid, extensive sea-ice loss. Geophysical Research Letters 34, L24501, doi:10.1029/2007GL032043.

McDonald, L.L., Garner, G.W., and Robertson, D.G. 1999. Comparison of aerial survey procedures for estimating polar bear density: Results of pilot studies in northern Alaska. In: Garner, G.W., Amstrup, S.C., Laake, J.L., Manly, B.F.J., McDonald, L.L., and Robertson, D.G., eds. Marine mammal survey and assessment methods. Rotterdam, Netherlands: A.A. Balkema Publishers. 37-51.

Miller, S., Schliebe, S., and Proffitt, K. 2006. Demographics and behavior of polar bears feeding on bowhead whale carcasses at Barter and Cross islands, Alaska, 2002-2004. OCS Study, MMS 2006-14. Anchorage, Alaska: USDI, Minerals Management Service, Alaska OCS Region. 29 p. http://www. mms.gov/alaska/reports/2006rpts/2006_014.pdf.

Monnett, C., and Gleason, J.S. 2006. Observations of mortality associated with extended open-water swimming by polar bears in the Alaskan Beaufort Sea. Polar Biology 29:681 -687.

Monnett, C., and Treacy, S.D. 2005. Aerial surveys of endangered whales in the Beaufort Sea, fall 2002-2004. OCS Study, MMS 2005-037. Anchorage: USDI, Minerals Management Service, Alaska OCS Region. 153 p. http://www.mms.gov/alaska/ reports/2005rpts/2005-037.pdf.

Moore, S.E. 2008. Marine mammals as ecosystem sentinels. Journal of Mammalogy 89:534-540.

Moore, S.E., and Huntington, H.P. 2008. Arctic marine mammals and climate change: Impacts and resilience. Ecological Applications 18(Supplement):S157-S165.

Norris, S., Rosentrater, L., and Eid, P.M. 2002. Polar bears at risk: A status report. Oslo, Norway: World Wildlife Fund International Arctic Programme. 27 p.

Norton, D., and Weller, G. 1984. The Beaufort Sea: Background, history, and perspective. In: Barnes, P.W., Schnell, D.M., and Reimnitz, E., eds. The Alaskan Beaufort Sea: Ecosystems and environments. Orlando, Florida: Academic Press. 3-19.

NSIDC (National Sea Ice Data Center). 2008. Arctic sea ice down to second-lowest extent; likely record-low volume. Boulder, Colorado: NSIDC, University of Colorado. http://nsidc.org/ news/press/20081002_seaice_pressrelease.html.

Obbard, M.E., Cattet, M.R.L., Moody, T., Walton, L.R., Potter, D., Inglis, J., and Chenier, C. 2006. Temporal trends in the body condition of southern Hudson Bay polar bears. Climate Change Research Information Note Number 3. 1-8. http:// assets.panda.org/downloads/obbard_et_al_ccrn_3.pdf.

Overpeck, J.T., Sturm, M., Francis, J.A., Perovich, D.K., Serreze, M.C., Benner, R., Carmack, E.C., et al. 2005. Arctic system on trajectory to new, seasonally ice-free state. Eos 86:309-316.

Perham, C. 2005. Proceedings: Beaufort Sea Polar Bear Monitoring Workshop. OCS Study, MMS 2005-034. Anchorage: USDI,
Minerals Management Service, Alaska OCS Region. 25 p. http://www.mms.gov/alaska/reports/2005rpts/2005-034.pdf.

Ramsay, M.A., and Stirling, I. 1988. Reproductive biology and ecology of female polar bears (Ursus maritimus). Journal of Zoology 214:601-634.

Regehr, E.V., Amstrup, S.C., and Stirling, I. 2006. Polar bear population status in the southern Beaufort Sea. Open-File Report 2006-1337. Reston, Virginia: U.S. Geological Survey. 20 p. http://pubs.usgs.gov/of/2006/1337/pdf/ofr20061337.pdf.

Regehr, E.V., Lunn, N.J., Amstrup, S.C., and Stirling, I. 2007a. Effects of earlier sea ice breakup on survival and population size of polar bears in Western Hudson Bay. Journal of Wildlife Management 71:2673-2683.

Regehr, E.V., Hunter, C.M., Caswell, H., Amstrup, S.C., and Stirling, I. 2007b. Polar bears in the southern Beaufort Sea I: Survival and breeding in relation to sea ice conditions, 2001-2006. Administrative Report. Reston, Virginia: U.S. Geological Survey. 50 p. http://www.usgs.gov/newsroom/ special/polar_bears/docs/USGS_PolarBear_Regehr_SB-II_ Estimation.pdf.

Reimnitz, E., Toimil, L., and Barnes, P. 1978. Arctic continental shelf morphology related to sea-ice zonation, Beaufort Sea, Alaska. Marine Geology 28:179-210.

Rigor, I.G., and Wallace, J.M. 2004. Variations in the age of Arctic sea-ice and summer sea-ice extent. Geophysical Research Letters 31, L09401, doi:10.1029/2004GL019492.

Rode, K.D., Amstrup, S.C., and Regehr, E.V. 2007. Polar bears in the southern Beaufort Sea III: Stature, mass, and cub recruitment in relationship to time and sea ice extent between 1982 and 2006. Administrative Report. Reston, Virginia: U.S. Geological Survey. http://www.usgs.gov/newsroom/ special/polar_bears/docs/USGS_PolarBear_Rode_SB-III_ BodyCondition.pdf.

Schliebe, S., Evans, T.J., Miller, S., Perham, C., Wilder, J., and Lierheimer, L.J. 2006. Polar bear management in Alaska 20002004. In: Aars, J., Lunn, N.J., and Derocher, A.E., eds. Polar bears: Proceedings of the 14th Working Meeting of the IUCN/ SSC Polar Bear Specialists Group. Occasional Paper of the IUCN Species Survival Commission No. 32. Gland, Switzerland: IUCN. 63-76. http://www.polarbearsinternational.org/rsrc/ Proc_Seattle05.pdf.

Schliebe, S., Rode, K.D., Gleason, J.S., Wilder, J., Proffitt, K., Evans, T.J., and Miller, S. 2008. Effects of sea ice extent and food availability on spatial and temporal distribution of polar bears during the fall open-water period in the southern Beaufort Sea. Polar Biology 31:999-1010.

Serreze, M.C., Holland, M.M., and Stroeve, J. 2007. Perspectives on the Arctic's shrinking sea-ice cover. Science 315: $1533-1536$.

Simmonds, M.P., and Isaac, S.J. 2007. The impacts of climate change on marine mammals: Early signs of significant problems. Oryx 41:19-26.

SPSS, Inc. 2001. SPSS for Windows, Release 10.1. Chicago: SPSS Inc.

Stirling, I. 1988. Attraction of polar bears Ursus maritimus to offshore drilling sites in the eastern Beaufort Sea. Polar Record 24:1-8. 
1990. Polar bears and oil: Ecological perspectives. In: Geraci, J.R., and St. Aubin, D.J., eds. Sea mammals and oil: Confronting the risks. New York: Academic Press. 223-234.

- 2002. Polar bears and seals in the eastern Beaufort Sea and Amundsen Gulf: A synthesis of population trends and ecological relationships over three decades. Arctic 55(Suppl. 1):59-76.

Stirling, I., and Derocher, A.E. 1993. Possible impacts of climatic warming on polar bears. Arctic 46:240-245.

- 2007. Melting under pressure-the real scoop on climate warming and polar bears. Wildlife Professional 1:24-27, 43.

Stirling, I., and Øritsland, N.A. 1995. Relationships between estimates of ringed seal and polar bear populations in the Canadian Arctic. Canadian Journal of Fisheries and Aquatic Sciences 52:2594-2612.

Stirling, I., and Parkinson, C.L. 2006. Possible effects of climate warming on selected populations of polar bears (Ursus maritimus) in the Canadian Arctic. Arctic 59:261-275.

Stirling, I., Lunn, N.J., and Iacozza, J. 1999. Long-term trends in the population ecology of polar bears in western Hudson Bay in relation to climatic change. Arctic 52:294-306.

Stroeve, J.C., Serreze, M.C., Fetterer, F., Arbetter, T., Meier, W., Maslanik, J., and Knowles, K. 2005. Tracking the Arctic's shrinking ice cover: Another extreme September minimum in 2004. Geophysical Research Letters 32, L04501, doi:10.1029/2004GL021810.
Stroeve, J.C., Holland, M.M., Meier, W., Scambos, T., and Serreze, M. 2007. Arctic ice decline: Faster than forecast. Geophysical Research Letters 34, L09501, doi:10.1029/2007GL029703.

Stroeve, J., Serreze, M., Drobot, S., Gearheard, S., Holland, M., Maslanik, J., Meier, W., and Scambos, T. 2008. Arctic sea ice extent plummets in 2007. Transactions of the American Geophysical Union 89:13-14.

Thomas, D.L., and Taylor, E.J. 2006. Study designs and tests for comparing resource use and availability II. Journal of Wildlife Management 70:324-336.

Thorndike, A.S., and Colony, R. 1982. Sea ice motion in response to geostrophic winds. Journal of Geophysical Research 87:5845-5852.

Treacy, S.D., Gleason, J.S., and Cowles, C.J. 2006. Offshore distances of bowhead whales (Balaena mysticetus) observed during fall in the Beaufort Sea, 1982-2000: An alternative interpretation. Arctic 59:83-90.

Tynan, C.T., and DeMaster, D.P. 1997. Observations and predictions of Arctic climatic change: Potential effects on marine mammals. Arctic 50:308-322.

Wiig, Ø., Aars, J., and Born, E.W. 2008. Effects of climate change on polar bears. Science Progress 91:151-173.

Williams, B.K., Nichols, J.D., and Conroy, M.J. 2002. Analysis and management of animal populations. New York: Academic Press. 